УДК 697.91.94.97

Н. В. Жихарєва, В. І. Перепека, М. Г. Хмельнюк

${ }^{1}$ Одеська національна академія харчових технологій, вул. Канатна, 112, Одеса, 65039, Україна

\title{
ЕНЕРГОЗБЕРЕЖЕННЯ ПРИ ЕКСПЛУАТАЦІЇ ПРИПЛИВНИХ СИСТЕМ ВЕНТИЛЯЦІЇ ТА КОНДИЦІЮВАННЯ ПОВІТРЯ
}

У роботі представлено маленький сегмент завдання енергозбереження в системах вентиляції та мікроскопічний сегмент величезної комплексної проблеми щцодо рачіонального використання енергії при обов'язковому зменшенні шкідливого впливу на екологію навколишнього середовища. Розглянуто методику розрахунку припливних систем вентиляиії і кондиціювання повітря. За изією методикою проведено аеродинамічний розрахунок припливної системи з вентилятором $і$ знайдено "робочу точку". На конкретному прикладі розглянуто методику оизінки технічних рішень, прийнятих на етапі проектування з метою зменшення сумарної вартості створення $і$ експлуатації припливної системи, щзо подає повітря в кілька промислових приміщень або технологічних агрегатів. Наведено кількісний техніко-економічний аналіз 3-х варіантів реалізації припливної системи, з розрахунком терміну окупності, щзо забезпечує подачу заданої кількості повітря з заданим напором в три приміщення. Надано конкретні рекомендації щุодо енергозбереження при експлуатаиії припливних систем вентилячії та кондиціювання повітря.

Ключові слова: Енергозбереження; Вентилячія; Кондиіюювання повітря; Повітроводи; Витрата повітря; Повітророзподілення; "Робоча точка"; Швидкість повітря.

Н. В. Жихарева, В. И. Перепека, М. Г. Хмельнюк

Одесская национальная академия пищевых технологий, ул. Канатная, 112, Одесса, 65039, Украина

\section{ЭНЕРГОСБЕРЕЖЕНИЕ ПРИ ЭКСПЛУАТАЦИИ ПРИТОЧНЫХ СИСТЕМ ВЕНТИЛЯЦИИ И КОНДИЦИОНИРОВАНИЯ ВОЗДУХА}

В работе представлен маленький сегмент задачи энергосбережения в системах вентиляции и микроскопический сегмент огромной комплексной проблемы по рациональному использованию энергии при обязательном уменьшении вредного влияния на экологию окружающей среды. Рассмотрена методика расчета приточных систем вентиляции и кондиционирования воздуха. По данной методике проведен аэродинамический расчет приточной системы с вентилятором и найдена «рабочая» точка. На конкретном примере рассмотрена методика оценки технических решений, принятых на этапе проектирования с иелью уменьшения суммарной стоимости создания и эксплуатации приточной системы, подающий воздух в несколько промышленных помещений или технологических агрегатов. Приведен количественный технико-экономический анализ 3-х вариантов реализации приточной системы, с расчетом срока окупаемости, обеспечивающей подачу заданного количества воздуха с заданным напором в три помещения. Даны конкретные рекомендации по энергосбережению при эксплуатации приточных систем вентиляции и кондиционирования воздуха.

Ключевые слова: Энергосбережение; Вентиляция; Кондичионирование воздуха; Воздуховоды, Расход воздуха; Воздухораспределение; "Рабочая точка"; Скорость воздуха.

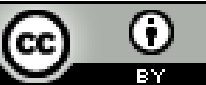

This work is licensed under the Creative Commons Attribution International License (CC BY) http://creativecommons.org/licenses/by/4.0/

\section{I. ВСТУП}

Огляд методів енергозбереження в системах вентиляції та кондиціювання через масштабність проблеми ставить техніко-економічну задачу, рішення якої може бути корисним на ранній стадії проектування. [1,2]

При створенні розгалужених мереж вентиляції, як правило, ставляться завдання по зниженню витрати споживаної енергії і капітальних витрат. У більшості випадків для зниження енергоспоживання потрібне збільшення капітальних витрат. Компромісний варіант зазвичай знаходять, оптимізуючи повну вартість капітальних і експлуатаційних витрат протягом повного циклу використання основного обладнання системи вентиляції.

У промисловості найчастіше використовуються вентилятори великих типономиналів, які забезпечують потребу в вентиляції декількох виробничих приміщень або агрегатів, що вимагають індивідуальної вентиляції. Аналіз існуючого вентиляційного обладнання показує, що часто вентилятори більшого номі- 
налу мають кращий (більш низький) важливий показник SFP, Вт/(м³/год) (скорочена англ. "Spesific Fan Power"), що представляє собою відношення споживаної потужності вентиляційної установки до витрати повітря, яке подається з заданим напором. Ця обставина призводить до створення розгалужених мереж 3 різними потребами об'єктів у витраті і натиску повітря. Однак не завжди така кореляція має місце і крім того, як було зазначено зазвичай більш важлива сумарна вартість створення і експлуатації системи повітророзподілення протягом усього "життєвого циклу".

Відомі різні способи зменшення енергоспоживання в розгалужених системах вентиляції. Можна згадати деякі з ГНIX: зменшення витрати повітря в гілках, де $\epsilon$ його надлишок за рахунок введення додаткових аеродинамічних опорів, підбір більш ефективних вентиляторів з ЕС-електродвигунами, які мають більший ККД, підбір інших елементів припливної установки (перш за все фільтра і нагрівача) з меншим аеродинамічним опором, раціонального компонування, що забезпечує підключення "магістралі" ближче до виходу вентилятора та ін. Найчастіше такі технічні рішення призводять до підвищення капітальних витрат і не завжди можливо застосувати через дизайнерські та компонувальні обмеження на конкретному об'єкті. При цьому не завжди розглядається рішення використовувати вентилятор-доводчик на "магістралі", хоча в ряді випадків таке рішення дозволяє не тільки зменшити необхідний натиск основного великого вентилятора, але при цьому зменшити також його споживану потужність, його номінал i, відповідно, вартість. Необхідно відзначити, що вставка на вході в галузі додаткових аеродинамічних опорів у вигляді заслонок, шиберів, діафрагм зазвичай призводить до деякого збільшення шуму $[5,6]$.

У цій статті на конкретному прикладі розглянуто методику оцінки технічних рішень, прийнятих на етапі проектування з метою зменшення сумарної вартості створення і експлуатації припливної системи, що подає повітря в кілька промислових приміщень або технологічних агрегатів. Наведено кількісний техніко-економічний аналіз 3-х варіантів реалізації припливної системи, що забезпечує подачу заданої кількості повітря з заданим напором в три приміщення.

\section{II. РОЗРАХУНОК ПРИПЛИВНИХ СИСТЕМ ВЕ- НТИЛЯЦІї ТА КОНДИЦІЮВАННЯ ПОВІТРЯ}

Розрахунок систем вентиляції та кондиціювання повітря передбачає наступні етапи:

1. Визначення мінімального витрати припливного повітря відповідно до обов'язкових вимог чинних нормативних документів [5].

2. Складання попередніх схем припливної та витяжної вентиляції із зазначенням місць установлення вентиляційного обладнання, розмірів повітропроводів, місць роздачі повітря в приміщення і витяжки його $з$ приміщення.
Розглянемо особливості розрахунку аеродинамічних характеристик систем вентиляції та кондиціювання повітря. [2, 3, 4]

Загальні втрати тиску, Па, в мережі трубопроводів для стандартного повітря визначаються за формулою

$$
\rho=\sum(R l+z)
$$

де $\rho$ - втрати тиску на тертя на розрахунковій ділянці мережі, Па, на 1 м; $l$ - довжина ділянки повітроводу, м; $z$ - втрати тиску на місцеві опори на розрахунковій ділянці мережі, Па.

Втрати тиску на тертя $\mathrm{R}$, Па, на 1 м в круглих повітропроводах визначають за формулою

$$
R=\frac{\lambda \cdot \rho \cdot v^{2}}{d \cdot 2}
$$

де $\lambda$ - коефіцієнт опору тертя; $d$ - діаметр повітроводу, м; $v$ - швидкість руху повітря в повітроводі, м/с; $\rho$ - щільність повітря, що переміщується у повітроводу, кт/м ${ }^{3} ; \rho v^{2} / 2$ - швидкісний (динамічний) тиск, Па. мулою:

Коефіцієнт опору тертя розраховується за фор-

$$
\lambda=0,11\left[\left(\frac{K e}{d}+\frac{68}{\mathrm{Re}}\right)\right]^{0,25}
$$

де $K e$ - абсолютна еквівалентна шорсткість поверхні повітроводу з листової сталі, що дорівнює 0,1 мм; $d$ - діаметр повітроводу, мм; $\operatorname{Re}-$ число Рейнольдса

Економічно доцільна швидкість руху $\left(v_{\mathrm{ek}}\right)$ повітря в повітроводах при механічному спонуканні з достатньою точністю визначається за формулою:

$$
\begin{aligned}
& V e k=26,4 \cdot L^{0 ., 04}\left(\frac{S_{\theta}}{S_{e л}}\right)^{0,32}\left(\frac{1}{p}\right)^{0,32}\left(\frac{1}{1+K_{z}}\right)^{0,32} \times \\
& \times\left[K_{1}\left(E_{\text {H }}+K_{\ni}\right)\right] 0,32\left(\frac{1}{n}\right)^{0.06}
\end{aligned}
$$

Методика визначення економічно доцільної швидкості руху повітря розроблена Б. А. Корепановим, де $L-$ витрата повітря, м ${ }^{3} /$, в ділянці; $S_{\text {в }}$ прямі витрати на прокладку повітропроводів, грн/м², 3 урахуванням витрат на теплоізоляційні матеріали і роботи. Якщо для прокладки повітроводів потрібні збільшення висоти приміщення, будування технічного поверху або підшивання стелі, слід враховувати додатково приведені витрати на будівельні роботи $-K_{1}$, на $\mathrm{M}^{2}$ повітроводу; $S_{\text {ел }}$ - річна плата за електроенергію, грн/(кВт·год), що визначається відповідно до Прейскуранту і залежить від тривалості роботи вентиляційної установки, годин, і енергопостачальної організа-

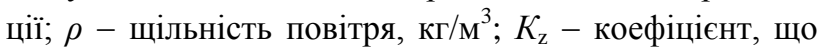
виражає відношення втрат тиску в місцевих опорах до 
втрат тиску на тертя; $K$ - коефіцієнт, що враховує в відносних одиницях накладні витрати в розмірі $13,3 \%$, планові накопичення в розмірі $8 \%$, а також добавки до норм витрат праці і заробітної плати при прокладці повітропроводів на висоті $(K=1,213 \div$ $1,277) ; E_{\mathrm{H}}-$ нормативний коефіцієнт ефективності капітальних вкладень $\left(E_{\mathrm{H}}=0,12\right) ; K_{\mathrm{e}}-$ коефіцієнт, що враховує в відносних одиницях амортизаційні відрахування на повне відновлення і капітальний ремонт. Відповідно до норм амортизаційних відрахувань по основних фондах народного господарства $K_{\mathrm{e}}=0,123 \div$ 0,243; $\eta$ - відносна шорсткість внутрішньої поверхні повітроводів, що показує, у скільки разів дійсна абсолютна шорсткість більше шорсткості металевих повітропроводів, що дорівнює $0,0001 \mathrm{м}$.

При визначенні швидкості руху повітря на ділянках конкретної вентиляційної мережі змінними величинами є $L, I, d, \zeta, K z, n, S_{\text {в. }}$

За даною методикою проведений аеродинамічний розрахунок припливної системи 3 вентилятором та знайдена "робоча" точка (рисунок 1).

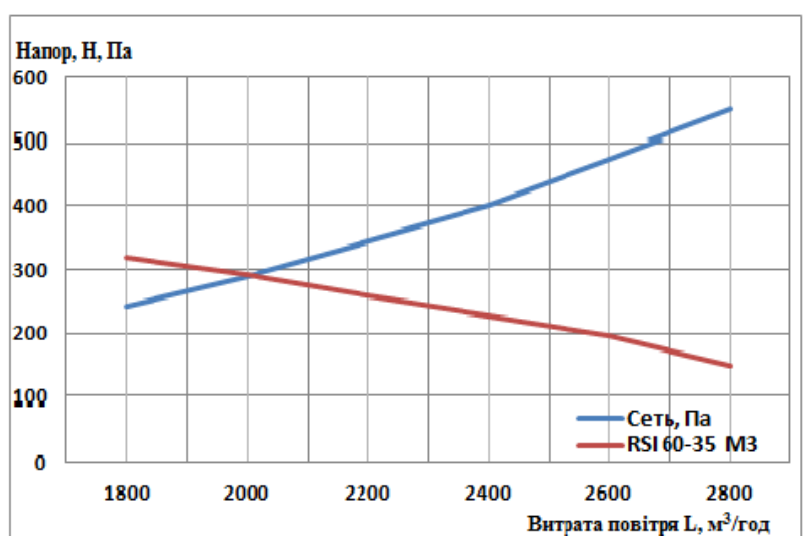

Рисунок 1 - Параметри в "робочий" точці: витрата $L=2000 \mathrm{~m}^{3} /$ час, напор $H=291$ Па, споживана потужність 400 Вт.

\section{III ЗНИЖЕННЯ СУМАРНОЇ ВАРТОСТI СТВО- РЕННЯ І ЕКСПЛУАТАЦІЇ РОЗГАЛУЖЕНИХ ПРИПЛИВНИХ СИСТЕМ ВЕНТИЛЯЦІЇ ТА КОНДИЦІЮВАННЯ ПОВІТРЯ}

Розглянемо конкретну технологію виробництва, яка вимагає подачі в три виробничих приміщення $8000 \mathrm{~m}^{3} /$ год повітря. При цьому по «магістральній» гілці (гілка 3 найбільшим опором) потрібна подача $2000 \mathrm{~m}^{3} /$ год повітря при напорі вентилятора, що витрачається на подолання опору всередині припливного агрегату, і всіх втрат по «магістралі» - 400 Па, а в два інших приміщення по $3000 \mathrm{~m}^{3} /$ год з напором вентилятора 200 Па. Без порушення технологічних вимог таку подачу повітря можна реалізувати одним вентилятором RSI 100-50 L3 (варіант 1), що подає повітря в розгалужену систему, або 3-ма вентиляторами: RSI 60-35 L1 - 2 шт та RSI 60-35 L3 - 1 шт (варіант 2), два 3 яких повинні подавати по 3000 м³ год при напоpi по 200 Па і один - $2000 \mathrm{~m}^{3} /$ год при напорі 400 Па. Передбачено застосування вентиляторів і супутнього устаткування шведської фірми Systemair. На передпроектній стадії для наближеної оцінки вартості варіантів допустимо прийняти величину коефіцієнта обліку вартості монтажу, витратних матеріалів та системи управління в діапазоні від 1.2 до 1.4 м [1].

Порівняння варіантів 1 і 2 показує, що при зменшенні споживаної потужності в разі використання вентиляторів за варіантом 2 на 33.89\%, сумарна вартість вентиляції за цим варіантом зростає на $33.78 \%$.

Розрахунок терміну окупності різниці капітальних затрат варіанту 2 і варіанту 1 за рахунок зниження енергоспоживання відповідних вентиляторів наведено при річному напрацюванні систем $\tau=7000$ годин, умовно прийнятому тарифі на електроенергію для промислових підприємств $3=1.8208$ грн (з ПДВ) за 1 кВт год.

Наближена оцінка терміну окупності варіанту 2 - 6 років. Дана оцінка $є$ оптимістичною, оскільки нереально прогнозувати коефіцієнт дискретності на такий довгий період і він не був врахований у формулі розрахунку терміну окупності в порівнянні двох варіантів. Природно, що в реальній практиці на вибір варіанта впливав би ще цілий ряд факторів, але все ж для більшості замовників термін окупності підвищених капітальних витрат, відповідних варіанту 2 6,05 року, а з урахуванням дисконту - майже 8 років, - виявився б неприйнятним.

Враховуючи вищесказане розглянемо потенціал використання для варіанта 1 вентилятора-доводчика RSI 60-35 M3 в "магістралі" (гілки з найбільшим опором), і основного вентилятора RSI 80-50 L3, підібраного з напором в робочій точці 200 Па.

Оцінка терміна окупності додаткових витрат на установку в "магістралі" вентилятора-доводчика показала, що споживана потужність варіанта 3 значно відрізняється від споживаної потужності Варіанта 2, а капітальні затрати набагато нижче.

Розрахунок терміну окупності різниці капітальних витрат варіанту 2 і варіанти 3 за рахунок зниження енергоспоживання відповідних вентиляторів проведено при річному напрацюванні систем $\tau=$ 7000 годин, та умовно прийнятому тарифі на електроенергію для промислових підприємств $3=1.8208$ грн (з ПДВ) [3] за 1 кВт год.

\section{VI. ВИСНОВКИ}

Виконавши розрахунки за розробленою програмою знайдено, що в більшості випадків найкращим $є$ варіант 3. Крім того можна констатувати, що при меншому відсотку повітря, що проходить по "магістралі" (в розглянутому прикладі це 25\% від загальної витрати повітря), ефективність застосування доводчика буде зростати. (таблиця 1) 
Таблиця 1 - Порівняння результатів розрахунків

\begin{tabular}{|l|l|l|l|}
\hline $\begin{array}{c}\text { № } \\
\text { Варіанту }\end{array}$ & $\begin{array}{c}\text { Споживана } \\
\text { потужність, } \\
\text { кВт }\end{array}$ & $\begin{array}{c}\text { Капітальні } \\
\text { витрати, } \\
\text { грн }\end{array}$ & $\begin{array}{c}\text { Сумарні } \\
\text { капітальні та } \\
\text { ксплуатаційн } \\
\text { витрати за } \\
\mathbf{7} \text { років, грн }\end{array}$ \\
\hline 1 & 2995 & 153532 & 420744 \\
\hline 2 & 1980 & 231835 & 408489 \\
\hline 3 & 2385 & 157845 & 370633 \\
\hline
\end{tabular}

У даній роботі розглянуто маленький сегмент завдання енергозбереження в системах вентиляції і кондиціювання повітря. Це мікроскопічний сегмент величезної комплексної проблеми щодо раціонального використання енергії при обов'язковому зменшенні шкідливого впливу на екологію навколишнього середовища. Оскільки проведений оцінний аналіз може бути виконаний на ранній стадії проекту, він є невід'ємною частини задачі енергозбереження. Вважаємо, що для оцінки необхідно відкоригувати всі ціни, тарифи і прогнозований дисконт за станом на момент виконання оцінки.

Використовуючи дані дослідження можливо ро зрахувати енергоекономічну систему повітророзподілення, що дозволяє підтримувати параметри повітря.

\section{ЛИТЕРАТУРА}

1. Перепека В. И. Расчеты систем кондиционирования и вентиляции. / В. И., Перепека, Н. В. Жихарева // - Одесса: «ТЭС», 2014. - 240 с.

2. Крупнов Б. В. К определению оптимальных диаметров воздуховодов систем В и КВ / Б. В. Крупнов // СОK - 2013. - СОК №3. - С. 16-20.

3. Жихарсва Н. В. Моделювання та оптимізація систем кондиціювання повітря: Навчальний посібник / Н. В. Жихарева // - Одеса: «ТЕС», 2016. - 170 с., додатки.

4. Жихарсва Н. В. Осоливості розрахунку теплоприпливів в приміщення при кондиціюванні повітря / Н. В. Жихарєва // Холодильна техніка та технологія. 2015. - Том 51, № 6. - С. 17-20.

5. Когут В. Е. Проектирование термоконденсатора эжектора / В. Е. Когут, Е. Д. Бутовский, Н. Г. Носенко // Холодильная техника и технология. - 2013. № 6 (146). - C. 45-48.

Отримана в редакції 03.02.2016, прийнята до друку 03.03.2016

N. V. Zhikhareva, B. I. Регерека, M. G. Khmelniuk

Odessa National Academy of Food Technologies, 112 Kanatnaja str., Odessa, 65039, Ukraine

\section{POWER SAVING AT OPERATION OF THE SUPPLY VENTILATION SYSTEMS AND AIR CONDITIONING}

The paper considers the method for calculating the branched air-supply systems, ventilation and airconditioning. This paper presents a small segment of power saving tasks in the ventilation and a microscopic segment of the huge complex problems rational use of energy with the necessary reduction of harmful impact on the ecology of the system environment. The method of calculating the air supply ICU-ventilation and air conditioning is considered. The aero-dynamic calculation of fresh air system with fan was carried out according to this methodology and the "working" point was found. In a specific example, the technique evaluation of technical solutions made at the design stage in order to reduce the total cost of establishing and operating air supply system that supplies air to several pro-industrial premises and technological units. Quantitative techno-economic analysis of 3 variants of the air-supply system is given (with calculations of the payback period) for applying of a predetermined amount of air with over-pressure data in three rooms. Special recommendations on power saving during exploitation of ventilation and air conditioning systems are also given.

Key words: Energy conservation; Ventilation; Air conditioning; Air ducts; Air flow; "Operating point"; Air velocity.

\section{REFERENCES}

1. Perepeka V. I., Zhikhareva N. V. (2014). The calculations of air conditioning and ventilation. Odessa «TEC», 240 p. (in Russian).

2. Ivashkevich A. A. (2013). Aвout energy saving in ventilashion system. Scientists note TOGU, Vol. 4, No. 3, 1689-1694 (in Russian).

3. Zhikhareva N. V. (2016). Modeling and optimization of air conditioning air: Uchebnoe posobye. Odessa: "TEC", 170 p., applications (in Russian).
4. Krupnov B. V. (2013). Determination of the optimal diameter duct systems in HF and CSR, SOK, No. 3, 16-20 (in Russian).

5. Zhikhareva N. V. (2015). Calculation features of heat gain in an air conditioning room. - Refrigeration engineering and technology, 51(6), 17-20 (in Russian).

6. Kogut, V. E., Butovskyi, I. D., Nosenko, N. G. (2013). Design thermocondenser-ejector. Refrigeration engineering and technology, No. 6 (146), 45-48 (in Russian). 